\title{
Learner Autonomy in University English Classrooms: Teachers' Perceptions and Practices
}

\author{
Chiew Yen Dwee (Corresponding author) \\ Center for Language Studies, Universiti Tun Hussein Onn Malaysia, 86400, Parit Raja, Johor, Malaysia \\ E-mail: dweeyen@gmail.com \\ Elizabeth M. Anthony \\ Centre for Language Studies, Universiti Tun Hussein Onn Malaysia, 86400, Parit Raja, Johor, Malaysia \\ E-mail: eliz@uthm.edu.my
}

Received: 17-09-2016

Published: 01-03-2017
Accepted: 14-11-2016

doi:10.7575/aiac.ijalel.v.6n.2p.19
Advance Access Published: January 2017

URL: http://dx.doi.org/10.7575/aiac.ijalel.v.6n.2p.19

The research is financed by the Ministry of Higher Education, Malaysia under the Fundamental Research Grant Scheme (FRGS), Vote 1477.

\begin{abstract}
While much has been written on the concept and development of learner autonomy, limited studies have investigated the perceptions and classroom practices of teachers in fostering learner autonomy. This paper sets out to examine what teachers think about learner autonomy as well as the strategies they use to develop autonomous learners in a university setting using a qualitative approach. Five English teachers were selected using purposive sampling and a semistructured interview was conducted with each of them to obtain in-depth data on their perceptions and teaching practices revolving around autonomous learning. The findings revealed that although university teachers possessed a fair understanding of what learner autonomy involves, there was a lack of focus in terms of developing learner autonomy in the classroom due to a number of challenges such as lack of teacher readiness, passive student attitude as well as the relevance and timing of English courses within the university curriculum.
\end{abstract}

Keywords: Learner autonomy, Teacher perception, Teaching practices, English classrooms

\section{Introduction}

Even though the Malaysian Education Blueprint (MEB 2013-2025) highlights the use of Autonomous Language Learning (ALL) to improve language proficiency among students, autonomous learning remains a crucial element that is missing from English language classrooms due to the exam-oriented system, as well as traditional teacher-centered approaches, widely used in Malaysia (Yunus and Arshad, 2014). It is fairly common to observe students assuming a passive role in the process of learning, waiting for their teachers to provide them with information and examination tips in schools. The ramification is students in this context become devout rote learners; memorising facts to pass examinations and not for long-term knowledge or skills gain.

The concept, as well as the importance attached to learner autonomy has been studied by many researchers (Holec, 1981; Little, 2007; Benson, 2013) and much has been written on how learner autonomy can be developed. Teachers, in particular, play a central role in ensuring that students develop the "psychological attributes and practical abilities involved in learner autonomy' (p.396) through classroom practice (Smith, 2008). However, the actual implementation of fostering autonomy among learners in the classroom leaves much to be explored as teachers differ in the way they interpret and carry out a lesson even if standardised guidelines and materials are provided (Wichayathian \& Reinders, 2015). It is thus crucial to find out what teachers think of learner autonomy and how they promote it in the teaching and learning process as teacher beliefs have a considerable impact on teaching practices. Therefore, this study sets out to examine the perceptions and current practices of English teachers in promoting autonomous learning among university students. The basic research questions that guide this research are:

1) What are the perceptions of English teachers towards learner autonomy?

2) What are the teaching practices used by English teachers to foster learner autonomy?

3) What are some of the challenges faced by English teachers in promoting learner autonomy?

\subsection{Learner Autonomy and Language Learning}

Be it in terms of language learning or language use, Little (2007) claims that the aim of learning is to create autonomous learners. An autonomous learner can be described as an individual who is able to manage and take responsibility for his or her own learning (Holec, 1981; Little, 1991). Nevertheless, this does not imply that students are expected to learn in 
isolation. As learning often occurs in a social context, autonomous learners should also be able to cooperate efficiently with other members of a group and assume responsibility for their respective roles (Smith, 2008).

Although developing learner autonomy indicates a shift from a teacher-centered classroom to one that is learnercentered, a teacher is still required to play a primary role by facilitating students to make learning happen. The teacher will share information when needed but will spend most of the time in the classroom getting students to be involved in authentic and challenging tasks such as problem-based learning. Three pedagogical principles facilitate the development of autonomy in language learners. They are:

- Learner involvement - engaging learners to share responsibility for the learning process (the affective and the metacognitive dimensions);

- Learner reflection - helping learners to think critically when they plan, monitor and evaluate their learning (the metacognitive dimensions);

- Appropriate target language use - using the target language as the principal medium of language learning (the communicative and the metacognitive dimensions)

(Little, 2006, p.2)

To put these three principles into practice, Little (2006) has provided a few suggestions on what teachers can do in the classroom to promote learner autonomy. Firstly, the teacher should use the target language to teach in the classroom and expect students to also put the target language into practice. The teacher should also guide the students in setting their personal learning goals, selecting suitable learning activities and working in groups using the target language. Another thing which could be done is to encourage students to maintain a learning portfolio where students document their learning so that it can be constantly reviewed. Finally, the teacher should facilitate the students to keep track of their individual and classroom improvement through regular evaluation sessions in the target language. What is evident from the suggestions above is the constant emphasis on the use of the target language in the classroom as language learning relies heavily on language use.

\subsection{Learner Autonomy in a Malaysian Context}

In a Malaysian context, the concept of learner autonomy is still in its early stages. It was first introduced as 'Self-Access Learning' in 1990 in primary schools, and later in 1995 in secondary schools for English subjects (Yunus and Arshad, 2014). Since then, a number of studies on learner autonomy have been done in a Malaysian context. Thang (2005) found that undergraduates learning English as a Second Language (ESL) lacked the qualities of being autonomous learners and heavily depended on their teachers during the learning process. This is echoed by the findings by Januin (2007) which indicated that students were not ready to engage in autonomous learning as most of them relied heavily on their teachers and were not confident about their own language learning ability.

Meanwhile, efforts have also been made by several researchers (Ahmad, Yaakub, Rahim and Rohani, 2004; Ismail, Singh and Abu, 2013) to instill learner autonomy in the teaching of English reading comprehension and academic writing with positive results. A separate study by Yunus and Arshad (2014) showed that ESL teachers in Malaysia have a rather positive opinion towards the implementation of autonomous language learning (ALL) although the situation of ALL among students remains discouraging.

While the studies mentioned above provide some insights on the development of learner autonomy in Malaysia, there is still a lack of literature when it comes to what teachers think or do in order to promote learner autonomy, especially in English classrooms at a tertiary level. Hence, this study aims to fill the gap by finding out university teachers' perceptions and teaching practices in fostering learner autonomy in English classrooms.

\section{Methodology}

A qualitative approach consisting of semi-structured interviews was selected as the primary tool for data collection in this study. This is because the researchers believe that every teacher has different interpretations of their own experiences based on their interactions with people around them as well as their environment and seeks to understand the reasons that lie behind those experiences. Five English language teachers were selected through purposive sampling which is the intentional selection of samples which possess certain characteristics or qualities in accordance with the research objectives (Coyne, 1997; Koerber \& McMichael, 2008). The participants who were involved taught English courses at tertiary level namely Foundation English, Academic English, Technical Writing, Technical Communication and Effective Communication and possessed teaching experience ranging from 3 to 20 years. All participants have an education background in TESL, which is also known as Teaching English as a Second Language, although the academic qualifications vary. Before the commencement of the interview, all participants signed a consent letter which indicated voluntary participation as well as the confidentiality of the data collected. The participants of the study will be addressed as T1, T2, T3, T4 and T5 respectively in the results and findings. Table 1 summarises the demographic profile of the participants. 
Table 1. Demographic Profile of the Respondents

\begin{tabular}{llll}
\hline Participants & $\begin{array}{l}\text { Teaching } \\
\text { Experience }\end{array}$ & Background & Academic Qualification \\
\hline T1 & 20 years & TESL & Ph.D \\
\hline T2 & 14 years & TESL & Masters \\
\hline T3 & 6 years & TESL & Masters \\
\hline T4 & 4 years & TESL & Masters \\
\hline T5 & 3 years & TESL & Degree \\
\hline
\end{tabular}

The semi-structured interview questions were developed based on the objectives of the study and revolved around teachers' understanding of learner autonomy, strategies used to promote learner autonomy as well as the challenges faced in the development of learner autonomy. The interview sessions were individually recorded, transcribed using TRANSANA v.2.61; a qualitative video analysis software (Fassnacht \& Woods, 2006), coded and categorised according to themes.

\section{Findings and Discussion}

In this section, the findings of the study will be presented along with a discussion. The responses obtained from the semi-structured interviews are discussed according to objectives of the study as well as the themes obtained from the coding process. Firstly, the perceptions of university English teachers towards learner autonomy will be presented. This includes how they define learner autonomy, their expectations of autonomous learners, skills they expect autonomous learners to possess as well as their role in promoting learner autonomy. Next, teaching strategies used by university English teachers to encourage learner autonomy among university students will be explained. Finally, challenges faced by teachers in fostering learner autonomy are identified in order to improve future teaching practices.

\subsection{Perception of University English teachers towards learner autonomy}

\subsubsection{Teachers' Expectations of Autonomous Learners}

The first question that the participants were asked to answer during the interview was to share their understanding about the term 'autonomous learners'. The two themes that emerged from the responses are 'taking responsibility' and 'flexibility' or 'freedom of choice'. For instance, T5 defines autonomous learners who 'choose how they want to learn' while T2 defines them as learners who are given 'the authority or the space and time to learn on their own'. The answers given correspond to the definition given by other researchers (Holec, 1981; Little, 2006; Benson, 2013) in the field of learner autonomy. This finding also corroborates with a study done by Hasim and Zakaria (2016) where most Malaysian ESL teachers were found to be aware of what learner autonomy entails.

Furthermore, the teachers unanimously expect that learners should take the initiative to learn and not passively await teachers to spoon-feed them. For instance, T3 shared that if students are not sure of any information delivered by the teacher, "they should ask...not just receiving and solving and accepting as it is" This is echoed by the opinions by T4 who said that the information shared in a classroom might be limited and therefore "for extra information they still need to look for it themselves".

An interesting point raised by T4 when it comes to expectations of autonomous learners is that learners need to have the eagerness and motivation to learn. She believes that if learners "are forced to do it, but they don't like it...they won't get the knowledge to the fullest". The nurturing of motivation among learners, in fact, important as research has shown it to be a vital factor for success in language learning (Dörnyei \& Ushioda, 2013).

\subsubsection{Teachers' Role in Promoting Learner Autonomy}

When the interview participants were asked whether it is possible to achieve full learner autonomy at a tertiary level, the responses obtained were mixed. On the one hand, there were teachers who believe that their students were already geared towards autonomous learning "Most of them are more inclined towards autonomous learning" [T2] due to the presence of technology while others think that it is difficult for students to change from "spoon-fed environment to independent learning or autonomous learning"'[T1]. A lack of confidence on the part of the educators could be traced from statements such as "it's difficult to train them to be autonomous in their learning" [T1] and "personally I don't think my students will do that [autonomous learning] '[T3]. The reasons for the mixed responses could be attributed to the differences in terms of the participants' teaching experience as well as the varying English language proficiency of the students involved.

When probed further, it was found that the participants had strong views regarding the role of teachers in promoting learning autonomy. T5 asserts that teachers still "play a big role in class" as students "need guidance". T1 and T2 agree that while flexibility should be given to students in order for them to be responsible for their own learning, teachers need to "guide them to achieve the learning objectives" [T2]. T4 rejects the idea of giving learners full autonomy because she fears that 'students will lose track of the right direction" and this resonates with T2's opinion where he mentioned his fear that "students would learn the things that are not targeted...stray away from the main focus". A simple example given by T4 is that students may have access to all types of technology but "whether or not it is directed towards something academic" depends very much on a teacher's guidance. The teachers see themselves akin 
captains who steer the ship and worry that students will not be able to achieve the learning outcomes if they allow students too much flexibility and freedom in learning. The key themes which emerged from the interviews on the role of teachers in fostering learner autonomy are that of supervision and facilitation, both of which have been mentioned in the literature (Little, 2006; Benson, 2013; Bajrami, 2015). All in all, the question of how much facilitation should be provided it is a tricky one to answer and perhaps T1 summarises it best when she said that while students should be encouraged to be autonomous, teachers should always "bear in mind what are the learning objectives" and that knowing what degree of freedom should be given to learners is something which "comes with experience".

\subsection{Skills needed to promote Learner Autonomy}

The participants shared several skills that they think are important for learners to have in order to become autonomous in their learning. In general, those skills can generally be categorized as study skills, critical thinking skills, information searching skills and team working. Selected interview excerpts are included in the table below to support the themes obtained.

Table 2. Summary of skills in promoting learner autonomy

\begin{tabular}{ll}
\hline Skills & Interview Excerpts \\
\hline $\begin{array}{l}\text { Information searching } \\
\text { skills/Research skills }\end{array}$ & They need to know where they can get the information... how to Google better [T4] \\
\hline Critical thinking skills & $\begin{array}{l}\text { Critical thinking that's the most important thing...for them to differentiate which } \\
\text { information is useful, which skill can be used to solve other problems, those things } \\
\text { require a lot of judgment [T2] }\end{array}$ \\
\hline Study skills & $\begin{array}{l}\text { Study skills..they don't know how to take notes based on they hear, understand and } \\
\text { write [T1] }\end{array}$ \\
\hline Team working skills & $\begin{array}{l}\text { They can of course work on their own, but if they have a team that can share } \\
\text { everything together...I think that would be even better[T3] } \\
\text { They need to learn about collaboration, team work... all these will contribute to } \\
\text { them being responsible to their learning[T1] }\end{array}$ \\
\hline
\end{tabular}

The participants think that possessing the skills mentioned above are most important for promoting autonomous learning because learners would be able to assume more responsibility for their learning and rely less on the teacher whenever they deal with assignments or projects in class. This finding is supported by Bajrami (2015) who mentioned that learners who possess a range of learning-to-learn skills have the potential to become better autonomous learners. Moreover, critical thinking skills have also been found to be positively correlated with learner autonomy (Elekaei, Faramarzi \& Tabrizi, 2016). More importantly, T3 mentioned that it is hoped that these skills "would help them not only in the subject [English] but also in other subjects", indicating that the transferability of what is learned to broader contexts (Little, 1991) is what makes developing autonomous learners such a priority in the education system.

\subsection{Teaching Practices to Foster Learner Autonomy}

The following table summarises the teaching practices used by teachers to facilitate the development of autonomous learners. The teaching practices that teachers believe are able to promote autonomy are encouraging discussion or interaction among students, activating students' prior knowledge, encouraging group work, conducting teacher/student reflection, selecting suitable tasks and allowing freedom of choice.

Table 3. Summary of teaching practices to foster learner autonomy

\begin{tabular}{ll}
\hline Teaching Practices & Interview Excerpts \\
\hline Freedom of choice & Presentation tools... You can use whatever means you find interesting [T2] \\
\hline Encourage & I like student interaction... I would find a way or find any activities to \\
discussion/Interaction & encourage this interaction more often in the classroom [T1] \\
& They need to do further discussion...it will help them with familiarising \\
themselves with learning on their own rather than be too dependent on the & lecturer [T1] \\
\hline Promote group work & $\begin{array}{l}\text { Each student actually just look for a portion of the information and when they } \\
\text { they are actually helping each other in understanding the concept of } \\
\text { communication [T1] } \\
\text { Instead of giving them a lecture, I divided them into groups and we talk about } \\
\text { communication [T1] }\end{array}$ \\
\hline
\end{tabular}


I did reflection at the end of the semester... write on Schoology or they talk to, among themselves, what they've learnt and so on [T1]

The way I deliver, the technology that I use, can it really trigger the students to join and participate in class...most importantly I will ask myself, do my students enjoy [T3]

Activate students' prior I don't give them like, straightaway the articles and what are the main ideas no
knowledge
I ask them to search for it first [T5]

I will ask them to...look for information, find something and share with us in the class. Then only I will start.[T3]

Selection of tasks-challenging, Whatever task I give in class must have a challenge [T2]

relevant, meaningful

Autonomous learners...must be sensitive with their surroundings... you must make materials that are also interesting and meaningful [T2]

We can give them a project...something practical [T4]

Firstly, giving students the freedom of choice in selecting how they want to learn is a strategy which resonates with one of the findings by Borg and Al-Busaidi (2012) where most teachers believe that allowing students to make choices and decisions aids in promoting learner autonomy. The next two teaching practices coincide with Little's (2006) principles to promote learner autonomy namely learner involvement and learner reflection. Teachers preferred the use of group discussion and promoting group work within the classroom help learners to develop the capacity to work independently and responsibly with their peers (Smith, 2008). While reflection has long been viewed as a fundamental part of learner autonomy (Hurd, 2005), it was interesting to note that the teachers not only thought that reflection was important for the students but also for teachers themselves to improve their teaching practices.

The teachers also believe that activating students' prior knowledge by getting them to do research before class or to share something with their classmates is useful because it means getting students to be more accountable for their own learning. Finally, the teachers also talked about the use of meaningful and challenging tasks to stimulate learner autonomy as these may motivate learners to be more engaged and motivated in their learning. Nonetheless, goal-setting and self-evaluation which are considered important components in promoting learner autonomy (Little, 2006) were not mentioned or emphasized by any of the teachers. This could mainly be due to the teachers' perception that they should be the ones in control of the learning objectives and outcomes as it is feared that "students would learn the things that are not targeted...stray away from the main focus" [T2], as mentioned in the section on teachers' role in promoting learner autonomy.

\subsection{Challenges in Fostering Learner Autonomy in the Classroom}

There are a number of challenges identified by the teachers in the development of autonomous learners in English classrooms. The first challenge is the lack of readiness among the teachers themselves to instill autonomy among the learners T3 acknowledged that "although I'm teaching in tertiary level now I do feel that I spoon-feed most of the time especially in terms of the content of the subject". This is not surprising as the English courses at tertiary level in Malaysia normally follow a curriculum and teachers are normally expected to deliver knowledge or information to their students. Furthermore, she added that she normally does not plan any "specific activities to promote autonomous learning" during class as the focus is on the course content. T2, on the other hand, brought up the difficulty in selecting materials and assessing learning outcomes for autonomous learning.

Secondly, the participants pointed out that the passive attitude and lack of interest in learning the English language among students could be a stumbling block in the development of autonomous learners. Students who "come to class just for the sake of coming to class"[T5], "always dependent on the teacher"[T1] as well as those who "just want to get what the teacher offers"[T4] are reasons cited by the participants as to why the development of autonomy among university students is difficult. Meanwhile, the lack of interest in learning English among students was observed by the teachers through their "last-minute work"[T4], how they "copy paste" their assignments [T5] and their reluctance to use English in class [T1]. These are pressing issues which teachers are struggling with hence leading to the lack of focus on promoting learner autonomy in the classroom.

The final challenge identified is the relevance and timing of the English courses within the university curriculum. T1 shared that in order for university students to be more autonomous, there is a need to review the position and relevance of English courses. She stressed that English courses should not be seen as a "standalone course" otherwise it would seem "irrelevant to them (students) and they will not be motivated". There is a need to link English courses with the other courses students are required to take in the university in terms of content as well as the transferability of skills. In terms of timing, for example, there "shouldn't be a long gap between Technical Writing and the final year project"'[T1] so that students will be able to see the relevance of what they are learning in an English course and be able to apply those skills in other courses effectively. Although the challenges identified in this study can be generally categorised as teacher factors, learner factors and institutional factors which are the same as the ones identified in a study by Borg \& Busaidi (2012) on teachers' beliefs and practices concerning learner autonomy, the findings in this study provide more depth by supporting each category with direct quotations taken from the interview participants. Moreover, the 
challenges specified here are contextualised within a setting of a Malaysian university and tackling those challenges may need to take into consideration the local education policies, cultural background of the teachers and students as well as the university curriculum which differ from the study conducted by Borg \& Busaidi (2012) which was based in Oman.

\section{Conclusion}

This study has taken a qualitative approach to unearth the perceptions of teachers towards learner autonomy whereby the two themes which emerged were 'flexibility' and 'taking responsibility. Teachers see themselves playing a key role in facilitating the development of autonomous learners by equipping them with 'learning-to-learn' skills as well as steering them towards the achievement of the targeted learning outcomes. Furthermore, teaching practices which were found to be useful for promoting learner autonomy were encouraging freedom of choice, group work, interaction in the classroom, reflection, activating students' prior knowledge and selecting tasks which are challenging, meaningful and relevant for learners. The findings show that development of autonomy among learners is no easy task and requires orchestrated effort from not only teachers but also education policy makers, university authorities as well as the learners themselves in order to make it work. While the results of this small-scale qualitative study may not be generalised to other settings, it is hoped that it can serve as a reference for other studies with similar research objectives or contexts. For future research, it would be useful to conduct a large-scale study across universities in Malaysia to delve into learner autonomy through classroom observations and an analysis of learners' self-directed learning needs in order to develop an autonomous learning model for use in English language classrooms.

\section{References}

Ahmad, N., Yaakub, R., Rahim, M. A., \& Rohani, P. (2004). Towards Learner Autonomy in Teaching English in Malaysia. Retrieved from http://eprints.usm.my/135/1/Towards_Learner_Autonomy_In _Teaching_English_In_Malaysia.pdf

Bajrami, L. (2015). Teacher's New Role in Language Learning and in Promoting Learner Autonomy. Procedia-Social and Behavioral Sciences, 199, 423-427.

Benson, P. (2013). Teaching and researching: Autonomy in language learning. Routledge.

Borg, S., and S. Al-Busaidi. (2012). Teachers' Beliefs and Practices Regarding Learner Autonomy. ELT Journal, 66 (3),283-292.

Coyne, I. T. (1997). Sampling in qualitative research. Purposeful and theoretical sampling; merging or clear boundaries? Journal of advanced nursing, 26(3), 623-630.

Dörnyei, Z., \& Ushioda, E. (2013). Teaching and researching: Motivation. Routledge.

Elekaei, A., Faramarzi, S., \& Tabrizi, H. H. (2016). Autonomy, critical thinking and listening comprehension ability of Iranian EFL learners. International Journal of Applied Linguistics and English Literature, 5(2), 40-48.

Fassnacht, C. \& Woods, D.K. (2006). Transana (Version 2.12). University of Wisconsin: Madison, WI, USA

Hasim, Z., \& Zakaria, A. R. (2016). ESL Teachers' knowledge on learner autonomy. In Knowledge, Service, Tourism \& Hospitality: Proceedings of the Annual International Conference on Management and Technology in Knowledge, Service, Tourism \& Hospitality 2015 (SERVE 2015). CRC Press.

Holec, H. (1981). Autonomy and foreign language learning. Oxford: Pergamon.

Hurd, S. (2005). Autonomy and the distance language learner. In: Holmberg, Boerje; Shelley,

Monica and White, Cynthia eds. Distance education and languages: evolution and change. New perspectives on language and education. Clevedon, UK: Multilingual Matters, 1-19.

Ismail, N., Singh, D. S. R., \& Abu, R. (2013). Fostering Learner Autonomy and Academic Writing Interest via the Use of Structured E-Forum Activities Among ESL Students. Edulearn13 Proceedings, 4622-4626.

Januin, J. (2007). Exploring readiness for language learning autonomy among distance learners in Sabah, Malaysia. Asian Journal of Distance Education,5(1), 16-26.

Koerber, A., \& McMichael, L. (2008). Qualitative Sampling Methods A Primer for Technical Communicators. Journal of business and technical communication, 22(4), 454-473.

Little, D. (1991). Learner autonomy 1: Definitions, Issues and Problems. Dublin: Authentik.

Little, D. (2006). Learner autonomy: Drawing together the threads of self-assessment, goal-setting and reflection. European Centre for Modern Languages (ECML, Hrsg.), Training teachers to use the European Language Portfolio.

Little, D. (2007). Language learner autonomy: Some fundamental considerations revisited. Innovation in Language Learning and Teaching, 1(1), 14-29.

Malaysia Education Blueprint 2013-2025. (2013). Retrieved August 9, $2016 \quad$ from http://www.moe.gov.my/userfiles/file/PPP/Preliminary-Blueprint-Eng.pdf 
Wichayathian, N. \& Reinders, R. (2015): A teacher's perspective on autonomy and self-access: from theory to perception to practice, Innovation in Language Learning and Teaching, 1-16 DOI: 10.1080/17501229.2015.1103245

Smith, R. (2008). Learner autonomy. ELT journal, 62(4), 395-397.

Thang, S. M. (2005). Investigating Malaysian distance learners' perceptions of their English Proficiency Courses. Open Learning, 20(3), 243-256.

The New Straits Times. (2015, November 15). Poor English a Major Handicap. The New Straits Times. Retrieved from http://www.thestar.com.my/news/nation/2015/11/15/poor-english-a-major-handicap-its-not-just-young-doctorsworkers-in-various-sectors-too-have-a-weak/

Yunus, M. M., \& Arshad, N. D. M. (2014). ESL Teachers' Perceptions toward the Practices and Prospects of Autonomous Language Learning. Asian Social Science, 11(2), 41-51. 